\title{
1. Political economy and public finance: a brief introduction
}

\author{
Stanley L. Winer and Hirofumi Shibata
}

It is costly to build a fence or to purchase a chain. It is possible to prove that the no-fence, no-chain solution is more efficient than either, provided that we model the behavior of our dog in such a way that he respects the boundaries of our property. As we put this example from personal experience, the exercise seems, and is, absurd. But is it really very different from that procedure which argues that tax structure $\mathrm{X}$ is more 'efficient' than tax structure $\mathrm{Y}$ provided that we model the behavior of government in such a way that it seeks only to further efficiency in revenue collection?

Geoffrey Brennan and James Buchanan (1980, p. 193)

If the economist were to accept any kind of 'political constraint' on the tax system as true constraints on economic policy, much of the prescriptive power of welfare analysis would clearly be lost.

Agnar Sandmo (1984, p. 116)

The two quotes above illustrate the long-standing difference in perspectives that exists in the field of public economics, between those who think that the realities of collective choice must be formally acknowledged, and those who base their policy recommendations on the traditional social planning model of public policy in which political constraints do not play a formal role. The purpose of this book is to contribute to the dialogue between these two groups, in the belief that the future of both political economy and of normative public finance lies somewhere in between the two approaches. ${ }^{1}$

In this introductory chapter, we explain the structure of this book while also briefly introducing each of the chapters that are included in it. We note at the outset that the volume as a whole is not intended to provide a definitive account of every aspect of the vast territory that lies between public choice and public finance. The chapters included here are largely concerned with the contribution of political economy to public finance, rather than with why and how public finance can inform political economy. Moreover, it is fair to say that those who think that it is necessary to formally integrate a concern with political competition and political institutions into public economics are more heavily represented than are those who are less sanguine about the possibility of an integrated approach. 
In some parts of the book, the chapters are organized as debates. Comments by the participants on each others' views are also included in several instances, and at times these comments are rather pointed. With one exception, the individual chapters were presented as invited plenary addresses at the 57th Conference of the International Institute of Public Finance in Austria during the last week of August 2001. ${ }^{2}$

The lack of integration of political economy and public finance is, perhaps, a surprising state of affairs. As Geoffrey Brennan and Walter Hettich both point out in their contributions, the political economy of public finance in the second half of the last century emerged from the earlier work on public finance by Knut Wicksell (1896), Eric Lindahl (1919) and others. These early public finance scholars were concerned with the role of collective choice in determining the allocation of public and private resources, a role they felt was central to both positive and normative analyses of public policy.

To be sure, over the past two decades or so, public finance academics and practitioners have gradually become more concerned with formal political economy when the issues at hand require an understanding of why governments do what they do, or of why the public sector is organized in the way that it is. So much so that the importance of political economy in understanding why public policy evolves as it does is now widely accepted. One can see this acceptance in the choice of recent Ph.D. dissertation topics, in the professional journals, and in the nature of the papers presented at international meetings such as the 57th Conference of the International Institute of Public Finance from which this book has emerged.

With respect to the specification of what constitutes good or better policy, and in the giving of advice to policy makers, however, there is much less agreement between students of political economy and traditional public finance scholars about how to proceed in either theory or practice. There is only limited consensus, too, among political economists, as readers of this volume will discover. For these reasons, the book has been designed to emphasize normative issues.

\section{PART I: DOES PUBLIC FINANCE NEED POLITICAL ECONOMY?}

Let us consider for the moment the standard or traditional approach to normative analysis in public economics. This approach adopts the perspective of a benevolent social planner who is concerned with Pareto efficiency, or who is more broadly concerned with both the allocation and distribution of resources as these are represented in a social welfare function. At first glance 
there appear to be several problems with this approach, among which are the following:

1. The information requirements for solving a social planning problem in practical contexts are large. In this respect, social planning suffers from the problems faced by a central planner. Consequently, it is standard practice in doing applied work to make use of simplified rules, such as tax neutrality instead of optimal taxation (with its complex blueprints), as a way of coping with the information problem. But these rules tend to be ad hoc, leaving a challenging gap between the formal theory and policy recommendations.

2. Social planning appears to be at odds with the classical solution to the information problem, which is to decentralize decision making. Since the information required to implement a social planning solution is substantial, should not more emphasis than is usual in the traditional approach be placed on the design and implementation of decentralized political processes, so as to economize on information and coordination costs?

3. Social planning usually takes no account of the consequences of the collective choice process itself for the allocation and distribution of resources. But public policies are necessarily public, and collective choice is not neutral in its effects for various reasons and may itself be an object of concern, suggesting that collective choice be formally integrated into any normative policy analysis.

4. Since the general equilibrium structure of the existing political process is not typically imposed on the solution of the planner's problem, there is no guarantee that an optimal social plan for the public finances is consistent with the equilibrium of an acceptable political process. This line of thought suggests restricting the policies that a social planner can advocate to a set that is consistent with acceptable restrictions on the collective choice process.

One might reasonably respond to the last statement in the spirit of the opening quote by Agnar Sandmo, as one can to most of the points raised, by arguing that by not taking political factors into account, it is possible to retain the ability to think of new and superior policies. An initial counter to this defense of the traditional social planning approach is that by implicitly taking political outcomes as bad when compared to some ideal counterfactual, we will always discover that policy has been corrupted by politics, and surely not all aspects of the policy process in a competitive political system are undesirable.

The volume begins with two extensive, affirmative answers to the question 
of whether normative public finance needs political economy. Geoffrey Brennan provides a general overview of the relationship between political economy and public finance, and then proceeds to focus on two matters he considers to be at the core of the question: first, whether it is necessary to include political constraints when doing normative analysis, an issue raised in points (3) and (4) above; and second, what objective is to be sought by the policy analyst.

On the first matter, Brennan is decidedly against the current practice in public economics which is to formally avoid incorporating political constraints into formal normative analysis. On the second matter, he is much closer to the social planning tradition than might be expected from one of the leading public choice theorists. He argues for carefully preserving a role for moral philosophy when doing normative public finance.

Brennan then applies his views to analyze the choice between fiscal policy and regulation as governing instruments. Here he raises doubts about the desirability of relying on regulation rather than fiscal policy when these instruments are substitutable.

Albert Breton argues for a political economy of public finance in quite a different manner. Breton focuses on the meaning and role of political competition, which he claims is an essential element of any internally consistent theory of public finance, whether positive or normative. His argument cuts across points (2), (3) and (4) raised earlier.

For Breton, political competition is not just about elections, but must be conceived of more generally as competition between centers of power, some of which are not elected. In this framework, he argues, institutional features of fiscal systems that are often considered negatively in traditional public finance, or even in some approaches to political economy, are seen differently. For example, interest groups help to reveal information about preferences, the struggle between centers of power results in links between spending and taxing that are stronger than those generally assumed in the standard approach to public finance and, as a result, the excess burden of taxation will generally differ from what it is in an apolitical model which assumes a complete separation between the two sides of the budget.

\section{PART II SHOULD COLLECTIVE CHOICE PLAY A ROLE IN THE STANDARD OF REFERENCE USED IN NORMATIVE PUBLIC FINANCE?}

The chapters in the next two sections of the volume are motivated by the structure of neo-classical welfare economics. In the neo-classical approach, one begins with a standard of reference such as Pareto efficiency, and then 
asks under what conditions this standard will be achieved by an ideal allocation mechanism. The key result here is one of the crowning achievements of social science - the first theorem of welfare economics, also called the invisible hand theorem - which links the equilibrium of a competitive market and economic efficiency.

The next step in the neo-classical approach is to use an analysis of why this theorem fails as the basis for the design of public policy. This is the 'market failure' approach to policy analysis. Finally there is a third step, one not addressed in this book, that involves measuring the consequences for economic welfare of departures from the first-best, so as to know where to concentrate one's efforts to best effect. Benefit-cost analysis is an example of this third step, and the analogue in normative political economy remains to be developed.

Part II is directed towards the first step - the specification of a standard of reference - when collective choice is acknowledged. The debate spills over at various points to consider the same general issue that is taken up in Part I, though the discussion in Part II is somewhat more technical. There are two chapters in this part of the book, by Robin Boadway and Walter Hettich, as well as comments by them on each other's contribution. Comments on Boadway by William Niskanen and Geoffrey Brennan and a reply by Boadway are also included at the end of the section.

As we have noted earlier, no formal account is taken of collective choice or the political process in the traditional approach to welfare analysis. Politics is left outside the standard of reference employed in the analysis, as Sandmo reminds us, on the reasonable grounds that we need to think about how the outcome of the policy process can be improved. Only preferences, technology and endowments are used in defining the standard used to judge policy actions.

Robin Boadway argues that this approach to normative public economics remains appropriate and useful and, in contrast to Brennan, argues that it is not wise to allow formally for political feasibility constraints of various kinds in doing normative work. He thinks that the concept of political feasibility is an imprecise and malleable concept and, to further this argument, he includes in his chapter a critical review of two leading political economy models - the citizen candidate and probabilistic voting models - that might serve as a basis for incorporating such constraints. (The role of political feasibility in public finance returns in the comments on Boadway's chapter and in the chapter by Aníbal Cavaco Silva in Part IV.)

Boadway does not object to anyone raising political issues informally at the policy implementation stage, or even to other theorists including them in their work. But he sees the drafting of policy blueprints based on traditional welfare analysis as a vital part of the policy formation process. In this volume, 
Boadway is the (very able) defender of the traditional approach to normative public finance.

Walter Hettich thinks that the standard of reference in normative work should be cognizant of the existence of collective choice. The main argument, which he develops at length, is that progress in normative public finance requires the development of a more complete welfare analysis that is so cognizant. In Hettich's view, this should begin with an understanding of how an ideal allocation, however defined, can be achieved as a political equilibrium - an invisible hand theorem for political markets - and then proceed with a corresponding theory of 'political market failure'. Measurement of departures from a first-best defined in the presence of collective choice is also required. He argues that such a complete, normative political economy, paralleling the structure of neo-classical welfare economics, is within our reach, and he illustrates some of his arguments with reference to the analysis of taxation.

Boadway and Hettich then turn to each other's argument in their comments. The comments on Boadway by Niskanen and Brennan follow. It is better if we do not risk spoiling the reader's enjoyment of this exchange by revealing details of it here.

\section{PART III WHAT IS A 'FAILURE' IN A NON-MARKET OR POLICY PROCESS?}

The second step in the neo-classical approach to welfare economics involves the identification of political market or non-market failure. There has been a great deal of work on this topic in the last four decades, but it is still not clear what 'failure' means and whether and where it occurs. The two chapters in Part III, by Donald Wittman and William Niskanen, present opposing views about when the policy process fails. This part of the book is intended to be a more practical counterpart to the preceding debate between Boadway and Hettich.

Donald Wittman begins by tackling the view that pressure groups and political advertising distort the electoral process and result in inefficient outcomes. (The reader may want to compare and contrast this argument with that of Dennis Mueller in the next section.) Wittman argues that such conclusions are based on the view that uninformed voters are irrational. The argument here is informal, and readers may also wish to consult the technical counterpart to his chapter, part of which was presented at the IIPF Conference. ${ }^{3}$

Wittman also argues that political processes in all sorts of situations generally contain an invisible hand process. So much so that, in his view, we 
may rely on standard normative public finance to provide us with a predictive theory of what democratically elected governments actually do.

To say that William Niskanen takes a different view is an understatement. Niskanen thinks that government failure is an everyday occurrence, and is rooted in large measure in the same set of conditions as the failure of private markets. These conditions include asymmetric information, principal-agent problems, and insecure property rights. He sees the lack of effective constitutional limitations on the power of government as the most pressing contemporary issue to be faced in dealing with excessive and inefficient growth in the public sector, thereby adding a constitutional dimension to his vigorous defense of the standard approach to the theory of nonmarket failure.

Niskanen and Wittman then comment on each other's chapters. Perhaps Wittman could be said to be observing the half-full part of the democratic policy process, while Niskanen focuses (more usefully, he would say) on the half-empty part. Perhaps, but one suspects that the differences between them are more fundamental, involving the use of different standards of reference to judge observed policies. The debate here helps us to confront the question posed in the title of this section, even if it does not point the way towards consensus about how to identify policy failures in practice.

\section{PART IV WHAT HAVE WE LEARNED ABOUT THE THEORY AND PRACTICE OF PUBLIC FINANCE FROM THREE DECADES OF EMPIRICAL RESEARCH ON PUBLIC CHOICE?}

After three or four decades of empirical research on public choice, it is appropriate to stand back and ask what follows for the theory and practice of public finance from this large body of positive empirical research. Part IV of the book thus includes three contributions that admirably survey the last three decades of empirical work on public choice in three important areas: the role of special interest groups and the size of government (by Dennis Mueller), the effects of fiscal institutions (by Gebhard Kirchgässner), and experimental work on collective action (by Frans van Winden).

Dennis Mueller focuses on the role of interest groups and redistribution in explaining differences in the size of government in the USA and Europe. He argues that the evidence suggests that we cannot understand this difference with recourse to normative arguments for redistribution, and that the explanation is to be found in understanding why special interest groups are more likely to be effective in Europe than in the USA. His explanation rests on differences between the operation of European parliamentary democracy under proportional representation and the operation of the US congressional 
system. (Here he necessarily deals with the identification of political failure and also crosses over into the territory of the next chapter, by Kirchgässner.) Unlike the other two chapters in this part, Mueller argues for a specific reform of the fiscal policy process, in this case to avoid the worst features of interest group politics. This proposal involves identification of policies that are primarily redistributive in nature, and restrictions on who may vote on such issues.

Gebhard Kirchgässner surveys the enormous volume of empirical work on fiscal institutions that has emerged over the last three decades. He considers (i) the role of constitutional and statutory fiscal limitations; (ii) budgetary procedures; (iii) fiscal outcomes in direct and representative democracies; and (iv) the relationship of federalism and the size of government. It is clear from his review that institutions matter, and that they do so in specific ways. As with all the chapters in this section, the detailed review of the literature he provides should prove valuable in consolidating and advancing research in the field.

Frans van Winden's assigned task is to deal with experimental work on collective action. He begins with contributions to theory that stem from the limited success in experimental work of the standard homo economicus model, and the apparent role of bounded rationality (cognition) and bounded reasoning (emotion). Van Winden also draws conclusions from the literature about what we have learned concerning the rationale for government intervention, the role of lobbying, and methods of encouraging collective action. For example, he argues that the rationale for collective action needs to be rethought, as in many cases government action is not required, and that lobbying should be seen as being important for informed policy making. The implications of these conclusions for Wittman's and Mueller's arguments remain to be developed.

\section{PART V A PRACTITIONER'S VIEW OF THE POLITICAL ECONOMY OF REDISTRIBUTION}

No discussion of political economy and public finance is complete without consideration of the political economy of redistribution. Dennis Mueller's provocative chapter on this topic was introduced earlier. In addition, a public finance 'practitioner' was asked to give a different view of the political economy of redistribution. In Part V, Aníbal Cavaco Silva, who is both a professor of public finance and former prime minister of Portugal, presents his view of how a politician judges the political feasibility of a policy, generally defined by him as politicians' willingness to take policy actions to achieve desirable goals. While he does not address the issue of whether political 
constraints should be formally integrated into the underlying theory used to draw up policy blueprints, Cavaco Silva clearly advocates a greater concern among policy advisers with political feasibility. He then offers his view as to what sort of policy in the European Union towards income inequality is feasible in this sense, including greater targeting of transfer payments in order to finance more human capital formation.

The chapter is of heightened interest at least for two reasons: when he speaks of political feasibility, one recalls that he was the prime minister (interrupting his career as an academic) for much of a decade in the second half of the 1980s and the first half of the 1990s. But also, as Cavaco Silva notes, globalization and deeper economic integration in the European Union have led to a reduced concern with general income inequality and a greater emphasis on poverty policy, developments which Cavaco Silva thinks may be mistaken.

\section{PART VI WHERE DO WE GO FROM HERE?}

Short contributions by two scholars, one specializing in public finance, and the other in public choice, conclude the volume. The assigned task here is to be both retrospective and prospective, and it is a difficult one. Eugene Smolensky, a policy-oriented public finance scholar, attempts to place the political economy work that was presented at the 57th IIPF Conference in a larger context, comparing European and American styles of work, and suggests a greater emphasis be placed on the evaluation of specific programs and on political or social engineering. Heinrich Ursprung presents his view of the current state of political economy. Finally, Stanley Winer offers his reflections on how these two perspectives relate to some of the broader issues addressed in the book.

\section{NOTES}

1. In this introduction, and generally in the volume, the terms 'public finance' and 'public economics' are used interchangeably. The term 'political economy' is also used interchangeably with 'public choice' here, though some authors included in this volume find it useful to distinguish between the public choice school of political economy associated most notably with James Buchanan and Gordon Tullock, and other approaches to the integration of economics and the study of political behavior and institutions.

2. The Conference was held in Linz, Austria, August 27-30, 2001. The Chair of the Scientific Committee was Stanley L. Winer of Carleton University. The chapter by Albert Breton included here (as Chapter 3) was presented as a contributed paper, and all other chapters were presented in plenary sessions. All have been revised for this volume. Further information about the IIPF is provided in the Preface.

3. Wittman's technical papers are found on his web page, the URL for which is given in the References. 


\section{REFERENCES}

Brennan, Geoffrey and James Buchanan (1980), The Power to Tax: Analytical Foundations of a Fiscal Constitution, New York: Cambridge University Press.

Lindahl, Eric (1919), Die Gerechtigkeit der Besteuerung. Reprinted in part as 'Just Taxation: A Positive Solution' (transl. Elizabeth Henderson) in Richard Musgrave and Alan Peacock (eds), Classics in the Theory of Public Finance, New York: Macmillan, 1958.

Sandmo, Agnar (1984), 'Some Insights from the New Theory of Public Finance', Empirica, 2: 111-24.

Wicksell, Knut (1896). 'A New Principle of Just Taxation', in Richard Musgrave and Alan Peacock (eds), Classics in the Theory of Public Finance, New York: Macmillan, 1958. 